\title{
Prevalence of hepatitis $B$ and $C$ viruses infection among military personnel at Bahir Dar Armed Forces General Hospital, Ethiopia
}

Tigist Birku, Baye Gelaw, Feleke Moges and Abate Assefa*

\begin{abstract}
Background: Military personnel are high-risk people for parenteral and sexually transmitted diseases such as hepatitis B virus (HBV) and hepatitis C virus (HCV). Data regarding HBV and HCV prevalence among military personnel in Ethiopia is limited. Hence, the study aimed to determine sero-prevalence and associated risk factors of HBV and HCV among military personnel at Bahir Dar Armed Forces General Hospital, Ethiopia.

Methods: A cross-sectional study was conducted in a total of 403 military personnel from February to May 2015. Socio-demographic characteristics and risk factors were collected through face to face interview using structured questionnaire. HBV and HCV infection was determined using HBsAg and anti-HCV antibody rapid tests. Logistic regression analysis was employed to assess possible risk factors for HBV and HCV infections.
\end{abstract}

Results: The sero-prevalence of HBV and HCV infection were 4.2 and $0.2 \%$, respectively. None of the study subjects were co-infected with HBV and HCV. Higher prevalence of HBV infection (11.3\%) was observed in the age group of 40 and above. Being at the age of 40 years and above (COR 7.6; $95 \% \mathrm{Cl} 2.0-29.0, \mathrm{p}=0.003)$, history of nose piercing (COA 5.9; $95 \% \mathrm{Cl} 1.2-29.9, \mathrm{p}=0.033$ ) and sexually transmitted infection (COR 4.3; $95 \% \mathrm{Cl}$ 1.1-16.4, $\mathrm{p}=0.03$ ) were significantly associated with these viral hepatitis infections.

Conclusion: Intermediate prevalence of HBV and low prevalence of HCV were observed among military personnel. Strengthening HBV screening strategies among military personal may further reduce these viral diseases.

Keywords: Hepatitis B virus, Hepatitis C virus, Military personnel

\section{Background}

Viral hepatitis is an inflammation of the liver due to viral infections. The most common types of viruses that cause viral hepatitis are hepatitis B virus (HBV) and hepatitis $\mathrm{C}$ virus (HCV) [1]. HBV and HCV share some common mode of transmission such as parenteral route and unsafe sexual intercourse. Viral hepatitis is significant public health problem especially in resource-poor settings. Annually about 500,000-700,000 people die as a result of HBV infection and more than 350,000 people from HCVrelated liver diseases [2-4]. Worldwide, more than 240

\footnotetext{
*Correspondence: abezew@gmail.com

Department of Medical Microbiology, School of Biomedical

and Laboratory Sciences, College of Medicine and Health Sciences,

University of Gondar, Gondar, Ethiopia
}

million people are chronically infected with $\operatorname{HBV}[5,6]$ and 150 million people with HCV [2].

In Ethiopia, although nationwide survey report is lacking, an estimated prevalence of 10-15\% HBV infection and $2-5 \% \mathrm{HCV}$ infection were reported. More than $60 \%$ of chronic liver disease and up to $80 \%$ of hepato-cellular carcinoma were caused by HBV and HCV chronic infections $[7,8]$. In addition, the prevalence of viral hepatitis showed great variability among different risk groups that should be taken into consideration when designing a more appropriate epidemiological investigation. In this regard, 4.11-6.2 \% sero-prevalence of HBV has been reported among blood donors [9-11], 5.6 \% among HIV infected individuals [12], $4.7 \%$ among medical waste handlers [13], $10.9 \%$ among street dwellers [14] and $10.4 \%$ among prisoners [15]. The prevalence of $\mathrm{HCV}$ 
infection was reported $0.63-1.7 \%$ among blood donors [9-11], $0.7 \%$ among medical waste handlers [13] and $5 \%$ among HIV positive individuals [12].

In most cases, military people live in military camps which may contribute to predispose them to HBV and HCV transmission through some common routes. The risk of sharing utensils such as hair-brushes, combs, razors and toothbrushes is common among people living in groups that can facilitate transmission of the viruses [16]. Moreover, usually soldieries travel from place to place for different professional reasons and stay longer apart from their family. This may force soldiers to have multiple sex partners that can expose them for different sexually transmitted infections (STIs) including HBV and $\mathrm{HCV}$. Although several studies reported the prevalence of $\mathrm{HBV}$ and $\mathrm{HCV}$ infections among different risk groups, so far there is no published data about viral hepatitis prevalence among military people in the Amhara regional state of Ethiopia. Thus, this study primarily aimed to determine the sero-prevalence of HBV and HCV infections and associated risk factors among military personnel at Bahir Dar Armed Forces General Hospital, Ethiopia.

\section{Methods}

\section{Study setting and design}

The study was conducted at Bahir Dar Armed Forces General Hospital found in Bahir Dar town from the 1st of February to the 30th of May 2015. The town is located $578 \mathrm{~km}$ far from Addis Ababa. The hospital currently provides health service for more than 9000 military and military families. It has 5 wards with 200 beds for inpatient service. All military persons attending the hospital were eligible for the study. The sample size was determined using single population proportion formula with the assumption of $95 \%$ confidence interval (CI), $5 \%$ marginal error and $50 \%$ prevalence of HBV and HCV infection because there was no previous similar study and $5 \%$ none response rate. Therefore, the final sample size was determined 403. During the study period, a total of 1320 military patients were attended in the hospital and the study participants were recruited using systematic random sampling method.

\section{Data collection}

Socio-demographic characteristics and associated risk factors for HBV and HCV infections were collected using structured questionnaire by trained health officer. The study variables included in this study were age, sex, marital status, work experience, history of hospitalization, blood transfusion, surgical procedure, ear/nose piercing, dental extraction, tattooing, STI, multiple sexual partner, family history of liver disease, sharing of shaving blade or nail cutter. Three milliliters of venous blood was collected from each study participant by trained laboratory technologist. Serum was separated by centrifugation at $3000 \mathrm{rpm}$ for $5 \mathrm{~min}$. Each serum was subjected to HBsAg and anti-HCV antibody rapid tests (Shanghai Eugene Biotech co., Ltd) following the manufacturer's instruction. To ensure the quality of data positive and negative control sera were run following the manufacturer recommendation of the kit.

\section{Data analysis}

Data was checked and cleared before entry. Data was entered and analyzed using SPSS version-20 computer software. Descriptive statistics were used to analyze socio-demographic characteristics, prevalence of HBV and $\mathrm{HCV}$ infections. Logistic regression analysis was employed to assess the possible associated factors of $\mathrm{HBV}$ and $\mathrm{HCV}$ infections. Odds ratio (OR), confidence interval (CI) and $p$ value were computed to assess the presence and degree of association between dependent and independent variables. P-value $<0.05$ was considered statistically significant for all cases.

\section{Ethical consideration}

Ethical approval was obtained from School of Biomedical and Laboratory Sciences, College of Medicine and Health Sciences, University of Gondar ethical review committee. Official permission was obtained from Bahir Dar Armed Forces General Hospital higher management. Written informed consent was taken from each study participant and confidentiality was maintained at each level of the study. Individuals found HBV and/or HCV positive were linked to physician for appropriate management.

\section{Results}

\section{Socio-demographic characteristics}

A total of 403 military personnel were enrolled in this study. The majority of the study subjects $362(89.8 \%)$ were male and the mean age of the study participants was $32.6 \pm 7$ SD years. More than half of the military personnel $(53.3 \%)$ were married and only $10(2.5 \%)$ were widowed or divorced. Data on educational status showed that 194 (48.1\%) military personnel completed college or higher degree and only 26 (6.5\%) had elementary school education. The majority of the soldiers $(79.2 \%)$ were recruited from urban settings and $325(80.6 \%)$ of them were orthodox Christian by religion (Table 1 ).

\section{Sero-prevalence of HBV and HCV infection}

The overall sero-prevalence of $\mathrm{HBV}$ and $\mathrm{HCV}$ infections was 18/403 (4.5\%) of which 17 (4.2\%) was positive for $\mathrm{HBV}$ and only one individual was positive for $\mathrm{HCV}$. The point prevalence of HBV infection was 318.2/100,000 but that of HCV was $15.2 / 100,000$. However, none of the 
Table 1 Socio-demographic characteristics of military personnel and sero-prevalence of HBV and HCV at Bahir Dar armed force general hospital, 2015

\begin{tabular}{|c|c|c|c|c|c|}
\hline \multirow[t]{2}{*}{ Variable } & \multirow[t]{2}{*}{ Total n (\%) } & \multicolumn{2}{|l|}{ HBV } & \multicolumn{2}{|l|}{$\mathrm{HCV}$} \\
\hline & & Positive n (\%) & Negative $\mathrm{n}(\%)$ & Positive n (\%) & Negative $\mathrm{n}(\%)$ \\
\hline \multicolumn{6}{|l|}{ Sex } \\
\hline Female & $41(10.2)$ & $2(4.9)$ & $39(95.1)$ & 0 & $41(100)$ \\
\hline Male & $362(89.8)$ & $15(4.2)$ & $347(95.8)$ & $1(0.3)$ & $361(99.7)$ \\
\hline \multicolumn{6}{|l|}{ Age (years) } \\
\hline $20-29$ & $160(39.7)$ & $3(1.9)$ & $157(98.1)$ & 0 & $160(100)$ \\
\hline $30-39$ & $172(42.6)$ & $6(3.5)$ & $166(96.5)$ & 0 & $172(100)$ \\
\hline $40+$ & $71(17.6)$ & $8(11.3)$ & $63(88.7)$ & $1(1.4)$ & $70(98.5)$ \\
\hline \multicolumn{6}{|l|}{ Residence } \\
\hline Urban & $319(79.2)$ & $12(3.8)$ & $307(96.2)$ & $1(0.3)$ & $318(99.7)$ \\
\hline Rural & $84(20.8)$ & $5(6.0)$ & $79(94.0)$ & 0 & $84(100)$ \\
\hline \multicolumn{6}{|c|}{ Educational status } \\
\hline Elementary & $26(6.5)$ & 0 & $26(100)$ & 0 & $26(100)$ \\
\hline High school & $183(45.4)$ & $11(6)$ & $172(93.9)$ & $1(0.5)$ & $182(99.5)$ \\
\hline Collage+ & $194(48.1)$ & $6(3.1)$ & $188(96.9)$ & 0 & $194(100)$ \\
\hline \multicolumn{6}{|l|}{ Religion } \\
\hline Orthodox & 325 (80.6) & $14(4.3)$ & $311(95.7)$ & $1(0.3)$ & $324(99.7)$ \\
\hline Muslim & $42(10.4)$ & $2(4.8)$ & $40(95.2)$ & 0 & $42(100)$ \\
\hline Others & $36(8.9)$ & $1(2.8)$ & $35(97.2)$ & 0 & $36(100)$ \\
\hline \multicolumn{6}{|l|}{ Marital status } \\
\hline Single & $178(44.2)$ & $5(2.8)$ & $173(97.2)$ & 0 & $178(100)$ \\
\hline Married & $215(53.3)$ & $12(5.6)$ & $203(94.4)$ & $1(0.5)$ & $214(99.5)$ \\
\hline Widowed & $2(0.5)$ & 0 & $2(100)$ & 0 & $2(100)$ \\
\hline Divorced & $8(2.0)$ & 0 & $8(100)$ & 0 & $8(100)$ \\
\hline \multicolumn{6}{|c|}{ Work experience (year) } \\
\hline$<10$ & $179(44.4)$ & $5(2.8)$ & $174(97.2)$ & 0 & $179(100)$ \\
\hline $10-20$ & $183(45.4)$ & $10(5.5)$ & $173(94.5)$ & $1(0.5)$ & $182(99.5)$ \\
\hline $20+$ & $41(10.2)$ & $2(4.9)$ & $39(95.1)$ & 0 & $41(100)$ \\
\hline
\end{tabular}

soldiers were co-infected by HBV and HCV. Higher prevalence of HBV infection 8/71 (11.3\%) was found among soldiers with age $\geq 40$ years. Moreover, the sero-prevalence of $\mathrm{HBV}$ infection was relatively higher among rural dwellers 5/84 (6 \%) and married soldiers 12/215 (5.6\%) (Table 1).

\section{Risk factor analysis for hepatitis virus infection}

The majority of military people had history of hospitalization $(33.5 \%)$ and dental extraction (28.8\%). Thirtynine $(9.7 \%)$ soldiers had history of different surgical procedures and 14 (3.4\%) had multiple (more than two) sexual partners. Only 17 (4.2\%) soldiers had family history of liver disease. Bivariate logistic regression analysis showed that soldiers with an age $\geq 40$ years (COR 7.6; $95 \%$ CI 2.0-29.0, $\mathrm{p}=0.003$ ), history of nose piercing (COA 5.9; $95 \%$ CI 1.2-29.9, p = 0.033) and history of STI (COR 4.3; 95 \% CI 1.14-16.4, p =0.03) were significantly associated with hepatitis virus infections. However, study variables such as history of hospitalization, tattooing, dental extraction, family history of liver disease, ear piercing, war related injury, history of blood transfusion, number of sexual partners and sharing of shaving blade or nail cutter were not associated with infection caused by these hepatitis viruses (Table 2).

\section{Discussion}

The result of the present study showed that the seroprevalence of $\mathrm{HBV}$ infection among the military personnel was $4.2 \%$. The sero-prevalence of HBV infection was reported $3.0 \%$ among delivering women in Ethiopian [17]. Another report showed a 4.11 and $4.7 \%$ prevalence of $\mathrm{HBV}$ infection among blood donors and medical waste handlers [13]. On the other hand, higher prevalence of HBV infection was reported from Gondar town street dwellers (10.9\%) [14] and Woldia prisoners (10.4 \%) [15]. Higher prevalence of HBV infections was also observed in some other African countries among 
Table 2 Bivariate regression analysis of risk factors association with hepatitis virus infection among military patients at Bahir Dar armed force general hospital, 2015

\begin{tabular}{llll}
\hline Variables & Viral hepatitis & COR $(95 \% \mathrm{Cl})$ & P value \\
\cline { 2 - 3 } & $\begin{array}{l}\text { Positive } \\
\mathrm{n}\end{array}$ & $\mathrm{n}$ &
\end{tabular}

\begin{tabular}{lrrll}
\hline Sex & & & & \\
Female & 2 & 39 & 1 & \\
Male & 16 & 346 & $0.902(0.20-4.10)$ & 0.89 \\
Age & & & & \\
$20-29$ & 3 & 157 & 1 & \\
$30-39$ & 6 & 166 & $1.89(0.47-7.69)$ & \\
$\geq 40$ & 9 & 62 & $7.59(1.99-28.99)$ & 0.003
\end{tabular}

Current residence

$$
\text { Urban }
$$

Rural

Educational status

Up to 12
College and
above

Religion

Orthodox

Muslim + others

Marital status

Single

Married

Work experience

$$
<10
$$

$$
10-20
$$

$>20$

Hospitalization

$$
\text { No }
$$$$
\text { Yes }
$$

Tattooing

$$
\text { No }
$$$$
\text { Yes }
$$

Dental extraction

No
Yes

Surgical history

No
Yes

Number of sexual partner

$0 \quad 2$

$1 \quad 14$

\begin{tabular}{|c|c|c|c|c|}
\hline \multirow[t]{2}{*}{ Variables } & \multicolumn{2}{|c|}{ Viral hepatitis } & \multirow[t]{2}{*}{ COR $(95 \%$ Cl) } & \multirow[t]{2}{*}{ P value } \\
\hline & $\begin{array}{l}\text { Positive } \\
\mathrm{n}\end{array}$ & $\begin{array}{l}\text { Negative } \\
\mathrm{n}\end{array}$ & & \\
\hline \multicolumn{5}{|c|}{ Nose piercing } \\
\hline No & 16 & 376 & 1 & \\
\hline Yes & 2 & 8 & $5.85(1.15-29.9)$ & 0.033 \\
\hline \multicolumn{5}{|l|}{ STI } \\
\hline No & 15 & 368 & 1 & \\
\hline Yes & 3 & 17 & $4.33(1.14-16.39)$ & 0.031 \\
\hline \multicolumn{5}{|c|}{ War related injury } \\
\hline No & 15 & 326 & 1 & \\
\hline Yes & 3 & 59 & $0.91(.25-3.22)$ & 0.877 \\
\hline
\end{tabular}

$$
\geq 2
$$

Family history of liver disease

\begin{tabular}{lrrll} 
No & 16 & 369 & 1 & \\
Yes & 2 & 16 & $2.88(0.61-13.62)$ & 0.181 \\
Ear piercing & & & & \\
No & 15 & 326 & 1 & \\
Yes & 3 & 59 & $0.91(.25-3.22)$ & 0.877 \\
\hline
\end{tabular}

Table 2 continued

different population groups. For instance, a prevalence of $8.2 \%$ was reported in Sudan among healthy people [18], $23 \%$ in Nigeria among prisoners [19] and $11.9 \%$ among HIV positive patients in Nigeria [20]. The discrepancies in the prevalence of HBV infection among different study groups might be explained by the variation in predisposing conditions. Military people and street dwellers have higher opportunity to be exposed to infections transmitted through sexual intercourse and parenteral routes. In-contrast, the prevalence of HBV infection found in the current study was relatively higher than the findings reported from Pakistan $2.9 \%$ [21] and Greece $0.32 \%$ among military groups [22].

The prevalence of $\mathrm{HBV}$ and $\mathrm{HCV}$ infection found in the current study can be graded intermediate and low according to WHO criteria [23]. The prevalence of HBV infection can be graded high when the prevalence is $>8 \%$, intermediate when the prevalence is between 2 and $8 \%$ and low when the prevalence is $<2 \%$ [24]. Hepatitis $\mathrm{C}$ virus infection can be also graded high, moderate or low when the prevalence is $>3.5,1.5-3.5 \%$ and $<1.5 \%$ respectively [25]. In the current study, only one study subject $(0.2 \%)$ was positive for $\mathrm{HCV}$ infection. This prevalence is nearly similar to previous reports among medical waste handlers (0.7 \%) in Gondar, Ethiopia [13], among apparently health people in Nigeria $(0.8 \%)$, and Morocco $(0.62 \%)$, and among blood donors in Jordan $(0.8 \%)$ and in Pakistan (0.89 \%) [26-29]. Lower prevalence of HCV infection was also reported $(0.82 \%)$ among military groups in Kabul military training center [30]. On the other hand, relatively higher prevalence of $\mathrm{HCV}$ infection $(1.7 \%)$ was reported in Pakistan among military groups [21].

The current study showed significantly higher (11.3\%) prevalence of HBV infection among solders within the 
age group of $\geq 40$ years. Similarly, in China significantly different HBV clinical and virological characteristics among patients with chronic HBV infection at different age groups was reported. Among patients at the age of $\geq 40$ years, there were markedly more reactivation cases than in any other groups [31]. Moreover, it was also observed that by the age of 40 years, $87 \%$ of the Nigerian population has at least one HBV serologic markers [32].

In the current study, history of hospitalization, tattooing, dental extraction, ear piercing, war related injury, and sharing of shaving blade or nail cutter were not significantly associated with hepatitis virus infections. Contrary to this finding, a significant association between histories of blood transfusion, body tattooing, surgery and unsafe injection for HBV infections was reported among pregnant women at Bahir Dar, Ethiopia [33]. A similar study, which was conducted in Egypt, identified these variables as significant risk factors for HBV infection. Study participants with body tattoo on any part of their body were 5.7 times more likely to be HBsAg positive [34]. Furthermore, reports from Bamako, Mali indicated that body tattooing was a significant risk factor for HBV infection [35]. However, in this study history of STI showed significant association with HBV infection. Evidences demonstrate that military people are considered to be a gateway group for STIs [36]. Absence of HBV and HCV co-infection in this study is supported by a study conducted among blood donors in the Amhara and Tigray national state of Ethiopian [11]. A report from Nigeria among prisoners was found also only $0.07 \% \mathrm{HBV}$ and HCV co-infected individuals [19]. Therefore, HCV infection is uncommon among HBV positive patients and some authors describe mutual inhibition [37].

\section{Conclusion}

The prevalence of HBV and HCV infection among soldiers at Bahir Dar Armed Forces General Hospital was intermediate and low respectively. Higher prevalence of HBV infection was observed among soldiers with an age of $\geq 40$ years. Moreover, older age, history of STI and nose piercing were significantly associated with HBV and HCV infections. Strengthening HBV screening strategies among military personal may further reduce these viral diseases.

\section{Author's contributions \\ This work was carried out in collaboration of all authors. TB proposed the initial idea for the study. All authors contributed to the study design. TB, BG and FM collected all the data. All authors analyzed and interpreted the data and prepared the manuscript for publication. All authors read and approved the final manuscript.}

\section{Acknowledgements}

We would like to acknowledge the University of Gondar for all the support given for us to conduct the research. We would also like to extend our deepest thanks to Bahir Dar Armed Forces General Hospital manager for all the help and support given for us during data collection. We also thank all the study participants for their participation in the study.

\section{Competing interests}

The authors declare that they have no competing interests.

Received: 26 September 2015 Accepted: 19 November 2015 Published online: 01 December 2015

\section{References}

1. Gunn RA, Murray PJ, Ackers ML, Hardison WG, Margolis HS. Screening for chronic hepatitis $B$ and $C$ virus infections in an urban sexually transmitted disease clinic: rationale for integrating services. Sex Transm Dis. 2001;28(3):166-70.

2. WHO. Prevention and control of viral hepatitis infection. Framework for global action." http://www.who.int/csr/disease/hepatitis/GHP_framework.pdf. 2014.

3. Lai CL, Ratziu V, Yuen MF, Poynard T. Viral hepatitis B. Lancet. 2003:362(9401):2089-94.

4. Pachiadakis I, Pollara G, Chain BM, Naoumov NV. Is hepatitis C virus infec tion of dendritic cells a mechanism facilitating viral persistence? Lancet Infect Dis. 2005;5(5):296-304.

5. Tran TT, Hepatitis B. Virus in Pregnancy. Clin Liver Dis. 2013;1(2):29-33.

6. WHO. Guidelines for the screening, care and treatment of person hepatitis C infection. www.who.int/hiv/pub/hepatitis/hepatitis-c-guidelines/ en/. 2014.

7. Karoney MJ, Siika AM. Hepatitis C virus (HCV) infection in Africa: a review. Pan Afr Med J. 2013;14:44.

8. Bane A, Patil A, Khatib M. Healthcare cost and access to care for viral hepatitis in Ethiopia. IJIAS. 2014;9(4):1718-23.

9. Assefa A, Mathewos B, Alemu A, Addis Z, Alem M, Gizachew M. Hepatitis $B$ and $C$ viral infections among blood donors at Bahir Dar, Ethiopia. IJMRHS. 2013;2(3):624-30.

10. Tessema B, Yismaw G, Kassu A, Amsalu A, Mulu A, Emmrich F, Sack U. Seroprevalence of HIV, HBV, HCV and syphilis infections among blood donors at Gondar University Teaching Hospital, Northwest Ethiopia: declining trends over a period of five years. BMC Infect Dis. 2010;10(1):111.

11. Gelaw B, Mengistu Y. Prevalence of HBV, HCV and malaria parasiets among blood donors in Amhara and tigray regional states. Ethiop J Health Dev. 2007;2(22):3-7.

12. Wondimeneh Y, Alem M, Asfaw F, Belyhun Y. HBV and HCV seroprevalence and their correlation with CD4 cells and liver enzymes among HIV positive individuals at University of Gondar Teaching Hospital, Northwest Ethiopia. Virol J. 2013;10:171.

13. Anagaw B, Shiferaw $Y$, Anagaw B, Belyhun $Y$, Erku W, Biadgelegn F, Moges B, Alemu A, Moges F, Mulu A. Seroprevalence of hepatitis B and C viruses among medical waste handlers at Gondar town Health institutions, Northwest Ethiopia. BMC Res Notes. 2012;5:55.

14. Moges F, Kebede Y, Kassu A, Mulu A, Tiruneh M, Degu G, Adugna S, Alem A, Wale F. Sero-prevalence of HIV, hepatitis B infections and syphilis among street dwellers in Gondar city. Ethiop J Health Dev. 2006;3(20):160-5.

15. Berhe H, Yismaw G, Addis Z, H/slassie H, Anagawm B, Unakal C. Seroprevalence and associated risk factors of human immunodeficiency virus and hepatitis B virus infections among prison inmates. J Pharm Biomed Sci. 2012;30(30):1035-45.

16. Alavian SM. Military personals should be vaccinated against hepatitis $B$ infection. J Arch Mil Med. 2013;2(1):e16450.

17. Tegegne D, Desta K, Tegbaru B, Tilahun T. Seroprevalence and transmission of Hepatitis $B$ virus among delivering women and their new born in selected health facilities, Addis Ababa, Ethiopia: a cross sectional study. BMC Res Notes. 2014;7:239.

18. Abdallah MT, Mohamed HM, Ali AA. Seroprevalence and epidemiological factors of hepatitis B virus (HBV) infection in Eastern Sudan. Int J Med Med Sci. 2011;3(7):239-41. 
19. Adoga MP, Banwat EB, Forbi JC, Nimzing L, Pam CR, Gyar SD, Agabi YA, Agwale SM. Human immunonodeficiency virus, hepatitis $B$ virus and hepatitis $C$ virus: sero-prevalence, co-infection and risk factors among prison inmates in Nasarawa State, Nigeria. J Infect Dev Ctries. 2009;3(7):539-47.

20. Otegbayo JA, Taiwo BO, Akingbola TS, Odaibo GN, Adedapo KS, Penugonda S, Adewole IF, Olaleye DO, Murphy R, Kanki P. Prevalence of hepatitis $B$ and $C$ seropositivity in a Nigerian cohort of HIV-infected patients. Ann Hepatol. 2008;7(2):152-6.

21. Butt T, Amin MS. Seroprevalence of hepatitis B and C infections among young adult males in Pakistan. East Mediterr Health J. 2008;14(4):791-7.

22. German V, Giannakos G, Kopterides P, Liaskonis K, Falagas ME. Serologic indices of hepatitis B virus infection in military recruits in Greece (2004-2005). BMC Infect Dis. 2006;6(1):163.

23. Hou J, Liu Z, Gu F. Epidemiology and prevention of hepatitis B virus infection. Int J Med Sci. 2005;2(1):50-7.

24. Mahoney FJ. M. K. Hepatitis B vaccine. In: Plotkin SA, Orenstein WA, editors. Vaccines. 3rd ed. Philadelphia:WB Saunders Company; 1999. p. 158-82.

25. Mohd Hanafiah K, Groeger J, Flaxman AD, Wiersma ST. Global epidemiology of hepatitis $C$ virus infection: New estimates of age-specific antibody to HCV seroprevalence. Hepatology. 2013;57(4):1333-42.

26. Balogun TM, Emmanuel S, Ojerinde EF. HIV, hepatitis B and C viruses' coinfection among patients in a Nigerian tertiary hospital. Pan Afr Med J. 2012;12:100.

27. Baha W, Foullous A, Dersi N, They-they TP, El alaoui K, Nourichafi N, Oukkache B, Lazar F, Benjelloun S, Ennaji MM, Elmalki A, Mifdal H, Bennani A. Prevalence and risk factors of hepatitis $B$ and $C$ virus infections among the general population and blood donors in Morocco. BMC Public Health. 2013;13(1):50.

28. Al-Gani FA. Prevalence of HBV, HCV and HIV-1, 2 infections among blood donors in Prince Rashed Ben Al-Hassan Hospital in North Region of Jordan. IIBMR. 2011;2(4):912-6.
29. Khan A, Bukhari SS, Alvi MI, Qazi A. Seroprevalence of hepatitis B, hepatitis C and HIV in blood donors of Peshawar. GJMS. 2010;9(1):46-50.

30. Todd CS, Nasir A, Mansoor GF, Sahibzada SM, Jagodzinski LL, Salimi F, Khateri MN, Hale BR, Barthel RV, Scott PT. Cross-sectional assessment of prevalence and correlates of blood-borne and sexually-transmitted infections among Afghan National Army recruits. BMC Infect Dis. 2012;12(1):196

31. Wu D, Xu G, Lu S, Ma B, Miao N, Liu X, et al. Age versus clinical virological characteristics in chronic hepatitis B virus infection: a case series study in China. Eur J Gastroenterol Hepatol. 2012;24(4):406-13.

32. Amazigo $\cup O$, Chime $A B$. Hepatitis-B virus infection in rural and urban populations of eastern Nigeria: prevalence of serological markers. East Afr Med J. 1990:67(8):539-44.

33. Zenebe Y, Mulu W, Yimer M, Abera B. Sero-prevalence and risk factors of hepatitis $B$ virus and human immunodeficiency virus infection among pregnant women in Bahir Dar city, Northwest Ethiopia: a cross sectional study. BMC Infect Dis. 2014;14:118.

34. Zahran KM, Badary MS, Agban MN, Aziz NHA. Pattern of hepatitis virus infection among pregnant women and their newborns at the women's health Center of Assiut university, Upper Egypt. Int J Gynecol Obste. 2010;111:171-4.

35. Sidibe S, Sacko BY, Traoré I. Prevalence of serologic markers of the hepatitis B virus in pregnant women of Bamako, Mali. Bull Soc Pathol Exot. 2001;94(4):339-41.

36. Ndiaye AA, Fall IS, Lo G, Seck SM, Tall AB, Gueye B, Mbodj AB, Tal-Dia A. HBsAg seroprevalence among Senegalese militaries. Mil Med Res. 2015:2:5.

37. Tsega E, Mengesha B, Nordenfelt E, Hansson BG, Lindberg J. Prevalence of hepatitis B virus markers among Ethiopian blood donors: is HBsAg screening necessary? Trop Geogr Med. 1987;39(4):336-40.

\section{Submit your next manuscript to BioMed Central and we will help you at every step:}

- We accept pre-submission inquiries

- Our selector tool helps you to find the most relevant journal

- We provide round the clock customer support

- Convenient online submission

- Thorough peer review

- Inclusion in PubMed and all major indexing services

- Maximum visibility for your research

Submit your manuscript at www.biomedcentral.com/submit 